\title{
PENCOCOKAN KURVA PENDERITA COVID-19 DI SUMATERA BARAT DENGAN MODEL HAMPIR EKSPONENSIAL
}

\author{
WINDA ASFI LASIFA, SUSILA BAHRI, RIRI LESTARI \\ Program Studi S1 Matematika, \\ Fakultas Matematika dan Ilmu Pengetahuan Alam, Universitas Andalas, \\ Kampus UNAND Limau Manis Padang, Indonesia. \\ email : asfilasifawinda@gmail.com,susilabahri@sci.unand.ac.id,ririlestari@sci.unand.ac.id
}

Diterima 4 Agustus 2021 Direvisi 15 September $2021 \quad$ Dipublikasikan 21 Oktober 2021

\begin{abstract}
Abstrak. Dalam penelitian ini, dikonstruksi suatu model hampir eksponensial untuk total penderita Covid-19 di Sumatera Barat. Model dikonstruksi dengan melakukan pencocokan kurva terhadap data total penderita Covid-19 tersebut melalui beberapa tahapan pemodelan yaitu memplot data, pencocokan data dengan model eksponensial, linierisasi model eksponensial $y=A r^{x}$, penentuan nilai awal dan rasio dari model hampir eksponensial. Dari proses pemodelan diperoleh model matematika $\widehat{y}=38,0216(1,0257)^{x}$ yang menunjukkan bahwa data penderita Covid-19 pada tanggal 26 Maret 2021 hingga 17 Oktober 2021 di Sumatera Barat itu tertutup terhadap model hampir eksponensial.

Kata Kunci: Pencocokan Kurva, Model Regresi, Linierisasi, Model Hampir Eksponensial.
\end{abstract}

\section{Pendahuluan}

Coronavirus disease 2019 (COVID-19) pertama kali ditemukan di Wuhan pada Desember 2019 [13] dan dinyatakan sebagai pandemi pada 09 Maret 2020 [7]. Covid19 merupakan jenis penyakit yang belum pernah ditemukan pada manusia yang dapat menyebar dari orang ke orang melalui droplet secara cepat [6].

Perkembangan pandemi Covid-19 di belahan dunia terus menunjukkan grafik naik. Terdapat 216 negara yang terkonfirmasi, salah satunya Indonesia pada 2 Maret 2020. Hingga 7 Juli 2021, Indonesia telah melaporkan 2,35 juta kasus positif yang menempati peringkat ke-6 kasus Covid-19 global [7].

Pandemi Covid-19 telah menyebar ke 34 provinsi di Indonesia, salah satunya Sumatera Barat yang dikonfirmasi pada 26 Maret 2020 di Bukittinggi. Hingga 7 Juli 2021, Sumatera Barat telah melaporkan sebanyak 54.186 kasus positif yang menempati peringkat ke-10 di Indonesia [11].

Seiring bertambahnya kasus Covid-19 yang terus meningkat setiap harinya, banyak peneliti melakukan penelitian mengenai Covid-19. Di antaranya penelitian

* penulis korenspondensi 
[9] yang membangun model representasi banyaknya kasus COVID-19 dengan menggunakan model Richards Curve.

Model matematika adalah ekspresi matematika yang diturunkan dari suatu fenomena yang melibatkan asumsi dan pendekatan untuk menggambarkannya secara sederhana. Oleh karena itu, fenomena Covid-19 ini dapat dikonstruksi melalui pencocokan kurva menjadi suatu model matematika yang merepresentasikan permasalahan yang terjadi guna mengetahui pola umum pertumbuhan total penderita Covid-19 [3].

Pencocokan kurva dapat dilakukan dengan metode regresi dan interpolasi. Regresi merupakan metode pencocokan kurva untuk mengetahui pola umum dari suatu permasalahan, sedangkan interpolasi merupakan metode pencocokan kurva untuk mencari nilai atau titik antara pada suatu rentang data yang digunakan [14].

Faktanya, kurva peningkatan kasus positif Covid-19 tidak linier, melainkan eksponensial. Ini berarti bentuk kurva pola sebaran data tidak mendekati garis lurus, melainkan mengalami laju pertumbuhan. Oleh karena itu total penderita Covid-19 di Sumatera Barat dapat diketahui pola umum pertumbuhan total kasus positif Covid-19 dengan melakukan pencocokan kurva menggunakan metode regresi.

\section{Landasan Teori}

\subsection{Pemodelan Matematika}

Pemodelan matematika merupakan proses dalam menurunkan model matematika dari suatu fenomena berdasarkan asumsi yang digunakan. Secara umum dalam menerapkan matematika untuk mempelajari suatu fenomena meliputi perumusan masalah, mencari solusi matematika, interpretasi solusi dari fenomena yang diteliti $[3]$.

\subsection{Pencocokan Kurva}

Pencocokan kurva adalah suatu proses pengkonstruksian sebuah kurva fungsi matematika yang menghampiri serangkaian titik data. Pencocokan kurva dapat digunakan dengan 2 metode yaitu regresi dan interpolasi [3].

Interpolasi merupakan metode pencocokan kurva untuk menentukan sejumlah titik-titik antara $x=a$ dan $x=b$ dalam domain. Regresi merupakan metode pencocokan kurva untuk mengetahui pola umum atau mengidentifikasi suatu fungsi dalam menggambarkan nilai yang diharapkan dari hubungan antar variabel [3].

\subsection{Model Pertumbuhan}

Model pertumbuhan merupakan kenaikan atau pertambahan nilai suatu besaran terhadap besaran sebelumnya. Salah satu model pertumbuhan seperti model eksponensial [2].

Model Eksponensial merupakan suatu fungsi yang variabel bebasnya merupakan pangkat dari suatu konstanta bukan nol. Secara umum, model ekponensial dapat dinyatakan sebagai berikut

$$
f(x)=p^{x}
$$


dengan $p$ adalah suatu basis, dimana $p>0, p \neq 1$.

\subsection{Linierisasi}

Linierisasi merupakan transformasi suatu kecendrungan non linier sehingga kecenderungannya menjadi linier yang bertujuan untuk menunjukkan hubungan linier antara masing-masing variabel. Transformasi dapat dilakukan dengan menggunakan fungsi balikan dari kecenderungan aslinya, misalnya data eksponensial dilinearkan dengan fungsi logaritma.

\subsection{Ukuran Ketetapan Model}

Ukuran ketepatan yang digunakan untuk mengetahui ketepatan suatu metode pendugaan yaitu nilai MAPE (Mean Absolute Percentage Error). MAPE merupakan ukuran ketepatan relatif yang digunakan untuk mengetahui persentase penyimpangan hasil pendugaan atau pemodelan, dengan persamaan sebagai berikut

$$
M A P E=\frac{1}{n} \sum_{x=0}^{n-1}\left|\frac{\left(y_{x}-\widehat{y}_{x}\right)}{y_{x}}\right| \times 100 \%
$$

dengan $\mathrm{n}$ : Banyaknya data pengamatan

$y_{x}$ : data pengamatan pada waktu ke- $x$

$\widehat{y}_{x}$ : data hasil pendugaan pada waktu ke- $x$.

Setelah diperoleh nilai MAPE, maka dapat dilihat interpretasinya pada tabel berikut [12].

Tabel 1: Interpretasi MAPE

\begin{tabular}{|l|l|}
\hline Nilai MAPE & \multicolumn{1}{c|}{ Interpretasi } \\
\hline$\leq 10 \%$ & Hasil pendugaan sangat baik \\
\hline $10 \%-20 \%$ & Hasil pendugaan baik \\
\hline $20 \%-50 \%$ & Hasil pendugaan cukup baik \\
\hline$>50 \%$ & Hasil pendugaan tidak akurat \\
\hline
\end{tabular}

\section{Total Penderita Covid-19 Dengan Model Hampir Eksponensial}

\subsection{Model Regresi}

Bentuk umum model garis regresi dapat dinyatakan dengan

$$
\begin{aligned}
& Y=\bar{y}+\frac{\sum[(x-\bar{x})(y-\bar{y})]}{\sum(x-\bar{x})^{2}}(x-\bar{x}) \\
& Y=\bar{y}+\frac{S_{x y}}{S_{x}^{2}}(x-\bar{x}),
\end{aligned}
$$

dengan $\bar{x}$ dan $\bar{y}$ adalah rata-rata dari nilai-nilai variabel bebas $x$ dan variabel tak bebas $y$ pada data, $(x-\bar{x})$ dan $(y-\bar{y})$ adalah deviasi $x$ dan deviasi $y, S_{x y}$ adalah 
jumlah hasil kali dari kedua deviasi, $S_{x}^{2}$ adalah jumlah hasil kuadrat dari deviasi $x$ $[2]$.

\subsection{Model Data Eksponensial}

Menurut [2], data dikatakan eksponensial jika rasio atau faktor pertumbuhan dari nilai data variabel $y$ berturut-turut adalah sama atau konstan.

Model data pertumbuhan eksponensial dapat dinyatakan sebagai berikut

$$
y=\text { nilai awal } \times \operatorname{rasio}^{x} .
$$

Apabila $a$ dinyatakan sebagai nilai awal dan $r$ dinyatakan sebagai rasio atau faktor pertumbuhan, maka persamaan (3.2) dapat dituliskan dengan

$$
y=a r^{x} .
$$

\subsection{Model Hampir Eksponensial}

Model hampir eksponensial dapat dikonstruksi dari suatu model eksponensial $y=a r^{x}$ pada persamaan (3.3). Dengan melakukan proses linearisasi menggunakan logaritma maka:

$$
\begin{aligned}
\log y & =\log \left(a r^{x}\right) \\
& =\log a+\log r^{x} \\
& =\log a+x \log r .
\end{aligned}
$$

Persamaan garis lurus dapat dituliskan dalam bentuk persamaan

$$
Y=A+b x,
$$

dengan $b$ adalah gradien dan $A$ adalah perpotongan.

Persamaan (3.4) identik dengan persamaan (3.5) maka diperoleh,

$$
\begin{aligned}
& \log y=Y, \\
& \log a=A, \\
& \log r=b .
\end{aligned}
$$

Dari (3.7) maka diperoleh

$$
a=10^{A},
$$

dan dari (3.8) maka diperoleh

$$
r=10^{b} .
$$

Jadi untuk mendapatkan model hampir eksponensial dari suatu data yang dikumpulkan, maka langkah-langkah yang diperlukan adalah:

(1) ubah data nilai fungsi $y$ menjadi $\log y$;

(2) dapatkan model garis regresi untuk data yang telah diubah;

(3) dapatkan nilai $r=10^{b}$ dan $a=10^{A}$. 
460 Winda Asfi Lasifa dkk.

\subsection{Pemodelan Total Penderita Covid-19 dengan Model Hampir Eksponensial}

Pada lampiran, dilampirkan data total penderita Covid-19 untuk daerah Sumatera Barat bulan Maret hingga Oktober tahun 2020. Plot data untuk data total penderita Covid-19 di Sumatera Barat adalah sebagai berikut

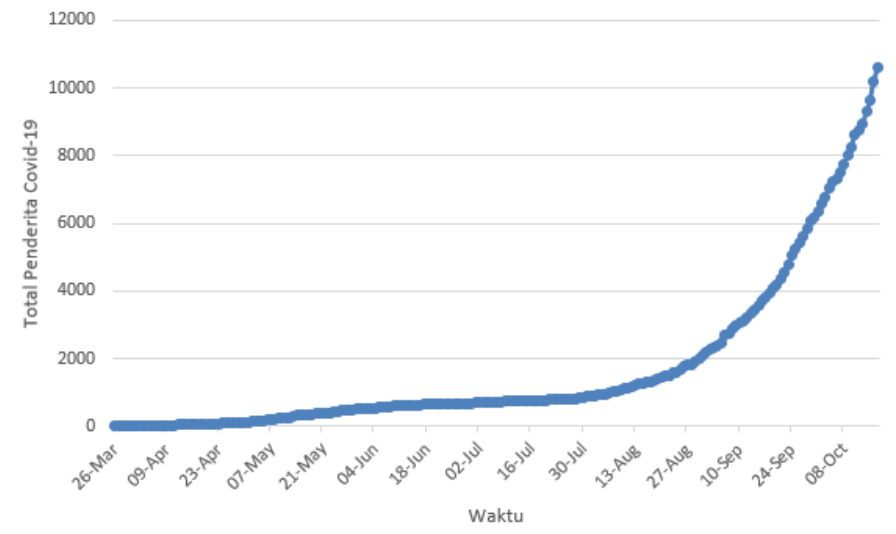

Gambar 1. Kurva data riil total penderita Covid-19 di Sumatera Barat

Data tersebut diolah dengan Microsoft Excel, dimana $x$ merupakan hari ke- dan $y$ menyatakan total penderita Covid- 19. Dari hasil pengolahan data diperoleh

$$
\bar{x}=102,5, \bar{y}=2,7871, S_{x}^{2}=728467,5, S_{x y}=8579,81 .
$$

Dengan menggunakan model garis regresi pada persamaan (3.1) diperoleh

$$
\begin{aligned}
Y & =2,7871+\frac{8579,81}{728467,5}(x-102,5) \\
& =2,7871+0,0012 x-1,2071 \\
& =1,58003+0,0012 x .
\end{aligned}
$$

Persamaan (3.11) merupakan bentuk dari persamaan garis lurus, sehingga dapat dinyatakan dengan

$$
Y=1,58003+0,0012 x
$$

dengan $A=1,58003$ dan $b=0,0012$.

Dengan menggunakan persamaan (3.9) diperoleh

$$
\begin{aligned}
a & =10^{A}, \\
& =10^{1,58003}, \\
& =38,0216,
\end{aligned}
$$


dan dengan menggunakan persamaan (3.10) diperoleh

$$
\begin{aligned}
r & =10^{b}, \\
& =10^{0,0012} \\
& =1,0257 .
\end{aligned}
$$

Sehingga model hampir eksponensial untuk total penderita Covid-19 di Provinsi Sumatera Barat adalah

$$
\widehat{y}=38,0216(1,0257)^{x} \text {. }
$$

Plot data untuk model hampir eksponensial total penderita Covid-19 di Provinsi Sumatera Barat adalah sebagai berikut.

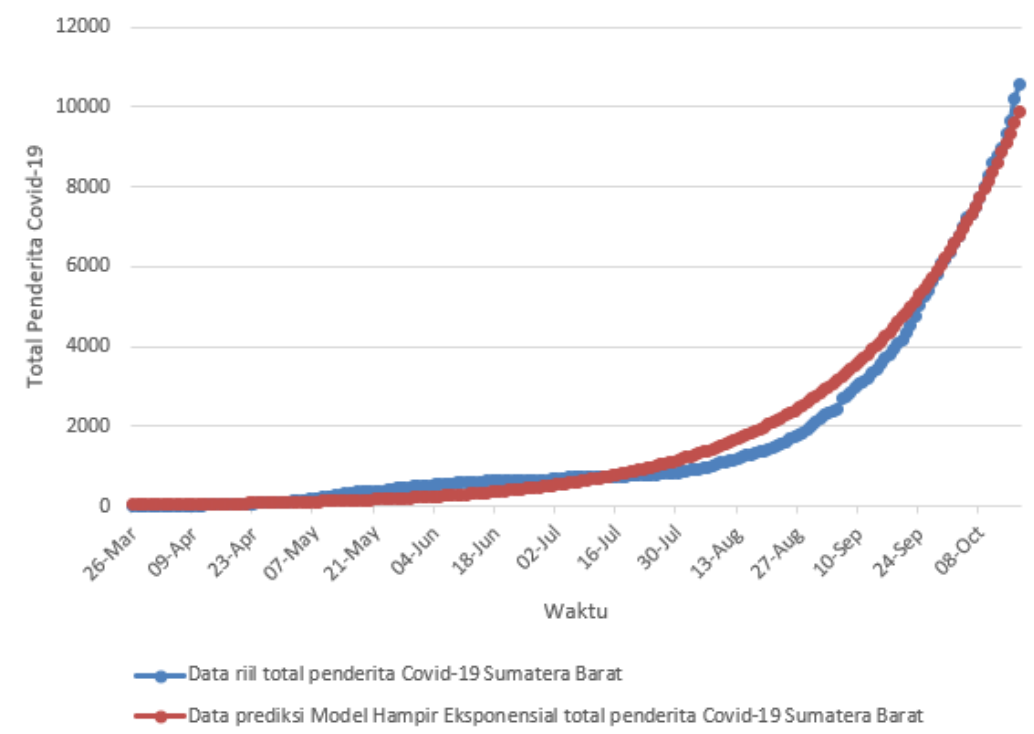

Gambar 2. Kurva total penderita Covid-19 di Sumatera Barat

\subsection{Interpretasi Model}

Dari data total penderita Covid-19 di Sumatera Barat diperoleh model hampir eksponensialnya yaitu

$$
\widehat{y}=38,0216(1,0257)^{x} .
$$

Pada model diperoleh nilai awal pendugaannya adalah 38,0216 dan laju pertumbuhannya sebesar 1, 0257. Dapat diketahui bahwa laju pertumbuhan tersebut merupakan basis dari model. Dapat dilihat bahwa basis model yang diperoleh bernilai besar dari 1, sehingga kurva yang dihasilkan akan mengalami pertumbuhan.

Plot pada Gambar 2 merupakan plot perbandingan kurva data riil total penderita Covid-19 Sumatera Barat dan data model pertumbuhan total penderita 
Covid-19 Sumatera Barat yang diperoleh dari model hampir eksponensial. Dapat dilihat bahwa data dari model hampir eksponensial yang diperoleh mendekati pola sebaran data riil total penderita Covid-19 Sumatera Barat. Dari model hampir eksponensial dapat diketahui pola umum sebaran data riil total penderita Covid-19 di Sumatera Barat. Hal ini dapat dilihat dari nilai MAPE (Mean Absolute Percentage Error) yang diperoleh berdasarkan (2.2) yaitu

$$
\begin{aligned}
M A P E & =\frac{1}{n} \sum_{x=0}^{205}\left|\frac{\left(y_{x}-\widehat{y_{x}}\right)}{y_{x}}\right| \times 100 \% \\
& =0,47 \times 100 \% \\
& =47 \% .
\end{aligned}
$$

MAPE yang diperoleh berada pada rentang 20\% - 50\% sehingga berdasarkan interpretasi MAPE pada Tabel 1 dapat disimpulkan bahwa model yang digunakan cukup baik atau layak digunakan dalam mengetahui pola umum sebaran data pertumbuhan total penderita Covid-19 Sumatera Barat.

\section{Kesimpulan}

Berdasarkan hasil dan pembahasan yang telah dilakukan pada bab sebelumnya didapatkan bahwa model hampir eksponensial total penderita Covid-19 di Provinsi Sumatera Barat adalah

$$
\widehat{y}=38,0216(1,0275)^{x},
$$

dapat dilihat kurva prediksi total penderita Covid-19 di Sumatera Barat mendekati pola sebaran titik data pengamatan dengan cukup baik, dan diperoleh hasil MAPE (Mean Absolute Precentage Error) untuk model hampir eksponensial data total penderita Covid-19 di Sumatera Barat adalah sebesar 47\%, sehingga berdasarkan interpretasi MAPE pada tabel 1 dapat disimpulkan bahwa model hampir eksponensial memiliki ketepatan yang cukup baik dan layak digunakan dalam mengetahui pola umum pertumbuhan data total penderita Covid-19 di Provinsi Sumatera Barat.

\section{Ucapan Terima kasih}

Penulis mengucapkan terima kasih kepada Ibu Arrival Rince Putri, Ibu Hazmira Yozza dan Bapak Syafrizal Sy yang telah memberikan masukan dan saran sehingga artikel ini dapat diselesaikan dengan baik.

\section{Daftar Pustaka}

[1] Basuki, A. 2014. Metode Numerik Interpolasi. Politeknik Elektronika Negeri Surabaya, Surabaya.

[2] Crauder, et. al. 2008. Functions and Change: A Modeling Approach to College Algebra and Trigonometry. National Science Foundation, New York.

[3] Giordano, F.R., D.W. Maurice, and P.F. William. 1997. A First Course in Mathematical Modeling. Brooks, London. 
[4] Herlambang. 2018. Regression. megabagus.id/regression/.

[5] Jo, B. 2017. Fungsi Eksponen. https://bukumaterimatematika.com

[6] Kementrian Kesehatan Indonesia. 2019. Coronavirus. Kemkes.go.id

[7] Komite Penanganan Covid-19 dan Pemulihan Ekonomi Nasional. 2021. Covid19. covid19.go.id.

[8] Munir, R. 2010. Regresi dan Interpolasi. Teknik Informatika : Institut Teknologi Bandung, Bandung.

[9] Nuraini, N., K. Khairudin, M. Apri. 2020. Data dan simulasi COVID-19 dipandang dari pendekatan model matematika. Institut Teknologi Bandung, Bandung.

[10] Silalahi, D. 2012. Interpolasi dan regresi. Scribd.

[11] Website Corona Sumbar. 2020. Covid-19. corona.sumbarprov.go.id.

[12] Wei.W.W.S. 2006. Time series Analysis : Univariate and Multivariate Methods. Second Edition. Pearson Education Inc, USA.

[13] World Health Organization. 2019. World Health Organization. https://www.who.int.

[14] Zakaria, A. 2013. Analisis Regresi dan interpolasi. Universitas Lampung 